\title{
FACTOR ANALYSIS METHOD APPLICATION FOR CONSTRUCTING OBJECTIVE FUNCTIONS OF OPTIMIZATION IN MULTIMODAL TRANSPORT PROBLEMS
}

\author{
Serhii Zabolotnii ${ }^{1}$, Artem Honcharov ${ }^{2}$, Sergii Mogilei ${ }^{3}$ \\ ${ }^{1}$ Cherkasy State Business-College, Cherkasy, Ukraine, ${ }^{2}$ Cherkasy State Technological University, Cherkasy, Ukraine, ${ }^{3}$ Rauf Ablyazov East European University, Cherkasy, \\ Ukraine
}

Abstract. The paper regards a specific class of optimization criteria that possess features of probability. Therefore, constructing objective function of optimization problem, the importance is attached to probability indices that show the probability of some criterial event or events to occur. Factor analysis has been taken for the main method of constructing objective function. Algorithm for constructing objective function of optimization is done for criterion of minimization risk level in multimodal transportations that demanded demonstration data. The application of factor analysis in classical problem solution was shown to give the problem a more distinct analytical interpretation in solving it.

Keywords: factor analysis, risk function, optimization criterion, multimodal transportation

\section{ZASTOSOWANIE METODY ANALIZY CZYNNIKOWEJ DO KONSTRUOWANIA FUNKCJI CELU OPTYMALIZACJI W PROBLEMACH TRANSPORTU MULTIMODALNEGO}

Streszczenie. Artykut dotyczy szczególnej klasy kryteriów optymalizacyjnych, które posiadaja cechy prawdopodobieństwa. W związku z tym, przy konstruowaniu funkcji celu problemu optymalizacyjnego pierwszorzędne znaczenie maja wskaźniki prawdopodobieństwa wystąienia określonego zdarzenia lub zbioru zdarzeń. Jako główna metodę konstruowania takiej funkcji celu wybrano analizę czynnikową. Algorytm konstrukcji funkcji celu optymalizacji wykonano dla kryterium minimalizacji poziomu ryzyka w przewozach multimodalnych - w tym celu wykorzystano dane demonstracyjne. Wykazano, że zastosowanie analizy czynnikowej w klasycznym sformułowaniu problemu badawczego pozwala nadać mu bardziej wyrazista interpretacje analityczna w jego rozwiązywaniu.

Słowa kluczowe: analiza czynnikowa, funkcja ryzyka, kryterium optymalizacji, transport multimodalny

\section{Introduction}

World globalization is inevitably affecting all human spheres. Besides, scientific and applied provision of human lives is to cater modern demands. Transportation in this respect appears to be a most urgent one. Passengers and goods deliveries are made for longer and longer distances and are required to be fast and of high quality, and also safe and inexpensive. Transportation costs being provided through free market economy competition the transportation safety risks are to be specially regarded.

Long distance transportations often require complicated logistics solutions. In passenger transportations, at least a changing or several of them are to be made, and in case of freight transportations, transmitting transportation knots (hubs or terminals) are to be arranged. However, their feature in common is that they both use several transportation means. Hence, transportations that consequently, or one by one, use several means of transportation are called intermodal. Those that use the means of transport simultaneously, or in parallel order, are called multimodal. Combined or mixed transportations are both intermodal and multimodal.

Dealing with transportation safety, presume the issue of risk level for multimodal freight transportations to be discovered in the paper. Multimodal transport problems as a separate class of optimization problems are taken for main models of these transportations. Hence, the research focuses on the problem of constructing objective functions to minimize risks in multimodal transportations.

Some analysts [13] consider intermodal transportations to be a part of multimodal ones. Such approach seems to be quite reasonable, though, to stick to distinct terminology, the notions of intermodal and multimodal transportations should be applied in the above mentioned sense.

Multimodal transportations are given quite a few investigations $[1,2,5,7,8,16,18,22]$, whereas a multimodal transport problem gets a vast mathematical analysis involved into the solution as well as possibilities of modern information technologies. Thus, in [9] a multimodal transport problem is revealed through various program means, while the problem regarded in the paper may be much more complex and applied to practical needs. It is presumably to be done through combining different optimization functions of a multimodal transport problem, for instance, a risk function.

While creating objective functions for minimizing risk in multimodal transportations, it should be for the first thing singled out what are parameters and variables of the objective function in a certain multimodal transport problem. Alike with a classical transport problem, the variables are to be indices of transportations amount between departure and delivery points, whereas this paper is focused on methods of finding out parameters of the risk objective function. Thus, in [20] there was an attempt of analyzing the issue under consideration, and, as a prospective research method, a method of group factor analysis was suggested [12]. However, this paper regards as the main method not a group, but an ordinary factor analysis.

The choice of research method accounts for several reasons. Firstly, factor analysis is the one quite spread and well-studied in applied science. It is especially popular in psychology and biomedicine $[3,10,11]$. Secondly, a group factor analysis applied, for instance, in machine training [19, 23] really seems to be quite a perspective, but cannot be fully applied in the given context.

\section{Problem statement and solution by factor analysis method}

Classical criterion for minimizing summary cost of multimodal transportations corresponds to objective minimization function given in [21] as follows:

$$
S=\sum_{i, j=1}^{m, n} a_{i j} x_{i j}+\sum_{i, j=1}^{m, n} b_{i j} y_{i j}+\sum_{i, j=1}^{m, n} c_{i j} z_{i j} \rightarrow \min
$$

where $i=\overline{1, n}, j=\overline{1, m}$ are $n$ of departure points and $m$ of delivery points correspondingly;

$x_{i j}, y_{i j}, z_{i j}$ - number of goods transported from $i$ departure point to $j$ delivery point by automobile, railroad and river means of transport correspondingly;

$a_{i j}, b_{i j}, c_{i j}$ - cost of transporting 1 item of goods from $i$ departure point to $j$ delivery point by automobile, railroad and river means of transport correspondingly;

$S$ - cost function. 
Objective function for a multimodal transport problem according to the criterion of minimal risk level is given in [20] and constructed similarly to objective function of minimizing cost for a classical (multimodal) transport problem. Therefore, this research regards the problem as a classical one.

With 3 means of transport, the objective function given in [21] as follows:

$$
R=\sum_{i, j=1}^{m, n} f_{i j} x_{i j}+\sum_{i, j=1}^{m, n} g_{i j} y_{i j}+\sum_{i, j=1}^{m, n} h_{i j} z_{i j} \rightarrow \min
$$

where $f_{i j}, g_{i j}, h_{i j}$ - risk coefficient of goods transportation from $i$ point of departure to $j$ point of delivery by means of automobile, railroad or river transport correspondingly;

$R$ - transportation risk function.

There is a number of ways to find out risk parameters $f_{i j}, g_{i j}, h_{i j}$ while constructing objective function (2). Here are two of them:

1. Risk in transporting one unit of load.

The method is a logical consequence of the problem under consideration: hence, each parameter $f_{i j}, g_{i j}, h_{i j}$ in (2) stands for damage risk while transporting 1 unit of load from $i$ point of departure to $j$ point of delivery by automobile, railroad and river means correspondingly.

Regard the example: in case transportation risk level of a load unit is $0.1(10 \%)$ then transportation risk level for 2 units will be $0.01(1 \%)$ etc. In mathematical aspect, it is obviously wrong but the problem does not require exact calculations of risk level, instead, it presupposes option of the least among all possible values. Therefore, such an approach to the problem can be considered as correct.

2. The grades of risk level according to number of transportations.

If to calculate yet more exact coefficients $f_{i j}, g_{i j}, h_{i j}$ within classical approach, the grades of risk level according to number of transportations might be suggested.

In this case, objective function (2) is to be illustrated by grade coefficients tables, for example (Table 1).

Table 1. The grades of risk level for automobile transportations

\begin{tabular}{|c|c|c|c|}
\hline Gradation level & $\min x_{i j}$ & $\max x_{i j}$ & Risk level \\
\hline 1 & 0 & $\mathrm{p}$ & $f_{i j}^{1}$ \\
\hline 2 & $\mathrm{p}+1$ & 1 & $f_{i j}^{2}$ \\
\hline 3 & $1+1$ & $\mathrm{q}$ & $f_{i j}^{3}$ \\
\hline 4 & $\mathrm{q}+1$ & $\ldots$ & $\cdots$ \\
\hline
\end{tabular}

In Table 1 , indices $\min x_{i j}$ and $\max x_{i j}$ stand for minimal and maximal value for the number of automobile transportations correspondingly, whereas $p, l, q \in R$ and $0<p<l<q$.

For railroad and river transportations, the related tables are similarly created.

The main advantage of applying classical approach to the problem is unification of functions (1) and (2). That may be necessary for a multicriteria multimodal transportation problem solution within which both objective functions (1) and (2) would appear simultaneously as optimization criteria.

In any case, there appears a necessity of calculating coefficients values $f_{i j}, g_{i j}, h_{i j}$ analytically. To this effect, factor analysis method, or factor approach, would be applied.
Expression (2) is written as follows:

$$
R=R_{a}+R_{r}+R_{w} \rightarrow \min
$$

where $R_{a}=\sum_{i, j=1}^{m, n} f_{i j} x_{i j}, \quad R_{r}=\sum_{i, j=1}^{m, n} g_{i j} y_{i j}, \quad R_{w}=\sum_{i, j=1}^{m, n} h_{i j} z_{i j}$ - is a summary risk for transportation loads from $i$ point of departure to $j$ point of delivery by means of automobile, railroad and river transport (taken separately), correspondingly.

Next, additional variables are to be introduced to mark risk factors: $\alpha_{i j}^{k}, \beta_{i j}^{k}, \gamma_{i j}^{k}$, which are values for $k$ risk factor when goods are transported from $i$ departure point to $j$ delivery point by means of automobile, railroad and river transport correspondingly.

According to methodology suggested in [12], it may be written as:

$$
\begin{aligned}
& f_{i j}=\sum_{i, j, k=1}^{m, n, v} \alpha_{i j}^{k} w_{\alpha}^{k}+o_{i j}^{f} \\
& g_{i j}=\sum_{i, j, k=1}^{m, n, v} \beta_{i j}^{k} w_{\beta}^{k}+o_{i j}^{g} \\
& h_{i j}=\sum_{i, j, k=1}^{m, n, v} \gamma_{i j}^{k} w_{\gamma}^{k}+o_{i j}^{h}
\end{aligned}
$$

where $w_{\alpha}^{k}, w_{\beta}^{k}, w_{\gamma}^{k}$ are weight coefficients of introducing (factor weights) of $k$ risk factor to general index of transportation risk by automobile, railroad and river transport (taken for certain);

$o_{i j}^{f}, o_{i j}^{g}, o_{i j}^{h}-$ "Gaussian noise" or in other words a value that does not essentially affect the ultimate calculated result and the value of which could be neglected.

Besides, in general case, it could be admitted:

$$
0<w_{\alpha}^{k}, w_{\beta}^{k}, w_{\gamma}^{k}<1, w_{\alpha}^{k}+w_{\beta}^{k}+w_{\gamma}^{k}=1 .
$$

Next, coming from (4) back to (3):

$$
\begin{aligned}
& R_{a}=\sum_{i, j, k=1}^{m, n, v}\left(\alpha_{i j}^{k} w_{\alpha}^{k}+o_{i j}^{f}\right) x_{i j} \\
& R_{r}=\sum_{i, j, k=1}^{m, n, v}\left(\beta_{i j}^{k} w_{\beta}^{k}+o_{i j}^{g}\right) y_{i j} \\
& R_{w}=\sum_{i, j, k=1}^{m, n, v}\left(\gamma_{i j}^{k} w_{\gamma}^{k}+o_{i j}^{h}\right) z_{i j}
\end{aligned}
$$

Through neglecting in (5) the values of components in "Gaussian noise", the ultimate expression is:

$$
\begin{aligned}
& R=\sum_{i, j, k=1}^{m, n, v}\left(\alpha_{i j}^{k} w_{\alpha}^{k} x_{i j}+\beta_{i j}^{k} w_{\beta}^{k} y_{i j}+\right. \\
& \left.+\gamma_{i j}^{k} w_{\gamma}^{k} z_{i j}\right) \rightarrow \min
\end{aligned}
$$

Taking into account that since $\alpha_{i j}^{k}, \beta_{i j}^{k}, \gamma_{i j}^{k}$ are matrix values for cases $i$ and $j$, and each of the elements $w_{\alpha}^{k}, w_{\beta}^{k}, w_{\gamma}^{k}$ is a vector, for instance, of the type $w_{\alpha}^{k}=\left(w_{\alpha}^{1} ; w_{\alpha}^{2} ; \ldots ; w_{\alpha}^{v}\right)$, therefore, the following equation is applied:

$$
f_{i j}=\left(\alpha_{i j}^{1}\right) \cdot w_{\alpha}^{1}+\left(\alpha_{i j}^{2}\right) \cdot w_{\alpha}^{2}+\ldots+\left(\alpha_{i j}^{v}\right) \cdot w_{\alpha}^{v}
$$

For parameters $g_{i j}, h_{i j}$ (7) is given in the same way.

That demonstrates that through factor analysis method the analytical expression which reveals the criterion of minimization of risk objective function for multimodal transport problem could be considerably specified. Besides, factor approach to the problem solution is proved to be a logical consequence of classical approach. 


\section{Problem solution for model example}

The solution of the given problem could be done by applying model data which would be a preparatory stage for ultimate risk transportation function (2) or (6) that could be solved through program aids $[4,6,14,15,17]$.

Main propositions for the problem are as follows:

1) Departure and delivery points are the same in number and are equal to $3: m=n=3$.

2) Risk factors are as well 3 in number: $v=3$.

Among risk factors are: damage $(k=1)$, disorder $(k=2)$, force majeur $(k=3)$.

3) Vectors of weight factors are as follows (for each transport means):

Automobile: $\bar{w}_{\alpha}^{k}=\left(w_{\alpha}^{1} ; w_{\alpha}^{2} ; w_{\alpha}^{3}\right)=(0.5 ; 0.4 ; 0.1)$

Railroad: $\bar{w}_{\beta}^{k}=\left(w_{\beta}^{1} ; w_{\beta}^{2} ; w_{\beta}^{3}\right)=(0.6 ; 0.25 ; 0.15)$

River: $\bar{w}_{\gamma}^{k}=\left(w_{\gamma}^{1} ; w_{\gamma}^{2} ; w_{\gamma}^{3}\right)=(0.45 ; 0.5 ; 0.05)$

4) Values for indices $\alpha_{i j}^{k}, \beta_{i j}^{k}, \gamma_{i j}^{k}$ are given as matrices (for each transport means):

Automobile:

$$
\begin{aligned}
\alpha_{i j}^{1} & =\left(\begin{array}{ccc}
0.1 & 0.2 & 0.15 \\
0.3 & 0.17 & 0.11 \\
0.15 & 0.07 & 0.13
\end{array}\right) \\
\alpha_{i j}^{2} & =\left(\begin{array}{ccc}
0.2 & 0.23 & 0.14 \\
0.31 & 0.07 & 0.21 \\
0.16 & 0.03 & 0.1
\end{array}\right) \\
\alpha_{i j}^{3} & =\left(\begin{array}{ccc}
0.15 & 0.12 & 0.25 \\
0.13 & 0.1 & 0.12 \\
0.19 & 0.08 & 0.09
\end{array}\right)
\end{aligned}
$$

Railroad:

$$
\begin{aligned}
& \beta_{i j}^{1}=\left(\begin{array}{ccc}
0.3 & 0.02 & 0.17 \\
0.13 & 0.08 & 0.1 \\
0.25 & 0.04 & 0.03
\end{array}\right) \\
& \beta_{i j}^{2}=\left(\begin{array}{lll}
0.02 & 0.15 & 0.11 \\
0.21 & 0.27 & 0.1 \\
0.06 & 0.23 & 0.01
\end{array}\right) \\
& \beta_{i j}^{3}=\left(\begin{array}{lll}
0.05 & 0.13 & 0.4 \\
0.14 & 0.19 & 0.12 \\
0.17 & 0.04 & 0.19
\end{array}\right)
\end{aligned}
$$

River:

$$
\begin{aligned}
\gamma_{i j}^{1} & =\left(\begin{array}{ccc}
0.2 & 0.1 & 0.12 \\
0.13 & 0.07 & 0.21 \\
0.19 & 0.01 & 0.11
\end{array}\right) \\
\gamma_{i j}^{2} & =\left(\begin{array}{ccc}
0.3 & 0.22 & 0.17 \\
0.11 & 0.03 & 0.2 \\
0.19 & 0.04 & 0.01
\end{array}\right) \\
\gamma_{i j}^{3} & =\left(\begin{array}{lll}
0.16 & 0.2 & 0.05 \\
0.14 & 0.15 & 0.23 \\
0.13 & 0.18 & 0.19
\end{array}\right)
\end{aligned}
$$

According to (7), they result in:

$$
\begin{aligned}
& f_{i j}=\left(\alpha_{i j}^{1}\right) \cdot w_{\alpha}^{1}+\left(\alpha_{i j}^{2}\right) \cdot w_{\alpha}^{2}+\left(\alpha_{i j}^{3}\right) \cdot w_{\alpha}^{3} \\
& g_{i j}=\left(\beta_{i j}^{1}\right) \cdot w_{\beta}^{1}+\left(\beta_{i j}^{2}\right) \cdot w_{\beta}^{2}+\left(\beta_{i j}^{3}\right) \cdot w_{\beta}^{3} \\
& h_{i j}=\left(\gamma_{i j}^{1}\right) \cdot w_{\gamma}^{1}+\left(\gamma_{i j}^{2}\right) \cdot w_{\gamma}^{2}+\left(\gamma_{i j}^{3}\right) \cdot w_{\gamma}^{3}
\end{aligned}
$$

Either, substituting exact values:

$$
\begin{aligned}
f_{i j} & =\left(\begin{array}{lll}
0.145 & 0.204 & 0.156 \\
0.287 & 0.123 & 0.151 \\
0.158 & 0.055 & 0.114
\end{array}\right) \\
g_{i j} & =\left(\begin{array}{ccc}
0.1925 & 0.069 & 0.1895 \\
0.1515 & 0.144 & 0.103 \\
0.1905 & 0.0875 & 0.049
\end{array}\right) \\
h_{i j} & =\left(\begin{array}{ccc}
0.248 & 0.165 & 0.1415 \\
0.1205 & 0.054 & 0.206 \\
0.187 & 0.0335 & 0.064
\end{array}\right)
\end{aligned}
$$

Coefficients $w_{\alpha}^{k}, w_{\beta}^{k}, w_{\gamma}^{k}$ could as well be presented as matrices, which would be valid in case values of factor weights are dependent on concrete points of departure and delivery. However, it does not especially affect the principle of finding out coefficients $f_{i j}, g_{i j}, h_{i j}$.

Thus, the model example demonstrates algorithm for calculating parameters $f_{i j}, g_{i j}, h_{i j}$ for objective function (2).

\section{Conclusions}

The paper regards the objective risk function of multimodal transport problem. It presents algorithm for calculating this function's parameters, together with factor analysis method for their definition.

The obtained results perfectly correlate with classical solution for a multimodal transport problem and could be further applied for solving multicriteria multimodal transportation problems. Risk objective function is constructed for three transport means: automobile, railway, river. Though, the problem considered in this form could be extended for any finite number of goods delivery. For a classical problem, application of factor analysis method results in more concrete analytical interpretation of this type of solution in the course of solving the problem. Correspondingly, similar approach could be applied for solving other problems of the type.

Further studies could be devoted to application of elements of this method as a group factor analysis while finding out values of parameters of minimization risk function. For example, creating different hierarchies of influence factors should be regarded to affect the ultimate risk objective function in the problem given.

\section{References}

[1] Ayed H., Galvez-Fernandez C., Habbas Z., Khadraoui D.: Solving timedependent multimodal transport problems using a transfer graph model Computers and Industrial Engineering 61, 2011, 391-401 [http://doi.org/10.1016/j.cie.2010.05.018].

[2] Ayed H., Habbas Z., Khadraoui D., Galvez-Fernandez C.: A parallel algorithm for solving time dependent multimodal transport problem. IEEE Conference on Intelligent Transportation Systems, Proceedings, ITSC, 2011, 722-727 [http://doi.org/10.1109/ITSC.2011.6082973].

[3] Boyd K. C.: Factor analysis. The Routledge Handbook of Research Methods in the Study of Religion 2013, 204-216 [http://doi.org/10.4324/978020315428122].

[4] Chandrakantha L.: Using excel solver in optimization problems. John Jay College of Criminal Justice of CUNY, 2014, 42-49. 
[5] Elias D., Nadler B., Nadler F., Hauger G.: OPTIHUBS - Multimodal Hub Process Optimization by Means of Micro Simulation. Transportation Research Procedia 14, 2016, 457-466 [http://doi.org/10.1016/j.trpro.2016.05.098].

[6] Ezeokwelume O.: Solving linear programming problems and transportation problems using excel solver. International Journal of Scientific \& Engineering Research 7(9), 2016, 134-142.

[7] Flórez J. E. Torralba A., García J, Linares López C., García-Olaya A. Borrajo D.: TIMIPLAN: An Application to Solve Multimodal Transportation Problems. Scheduling and Planning Applications Workshop 2010.

[8] García J., Florez J. E., Torralba A., Borrajo D., López C. L., García-Olaya A., Sáenz J.: Combining linear programming and automated planning to solve intermodal transportation problems. European Journal of Operational Research 227, 2013, 216-226.

[9] Honcharov A., Mogilei S.: Solving multimodal transportation problems by different program means. Bulletin of Cherkasy State Technological University $3,2020,67-74$

[10] Jennrich R. I., Bentler P. M.: Exploratory Bi-Factor Analysis. Psychometrika 76(4), 2011, 537-549 [http://doi.org/10.1007/s11336-011-9218-4].

[11] Journal I., Factor I.: Computational and Mathematical Methods in Medicine. Bio Med Research International 1, 2015, 2-4.

[12] Klami A., Virtanen S., Leppaaho E., Kaski S.: Group Factor Analysis. IEEE Transactions on Neural Networks and Learning Systems 26(9), 2015, 2136 2147 [http://doi.org/10.1109/TNNLS.2014.2376974].

[13] Lin C. C., Lin S. W.: Two-stage approach to the intermodal terminal location problem. Computers and Operations Research 67, 2016, 113-119 [http://doi.org/10.1016/j.cor.2015.09.009].

[14] Ovcharuk V., Vovkodav N., Kryvets T., Ovcharuk I.: Linear programming in Mathcad on the example of solving the transportation problem. Scientific Works of NUFT 21(4), 2015, 110-117.

[15] Sengamalaselvi J.: Solving transportation problem by using Matlab. International Journal of Engineering Sciences \& Research Technology 6(1), 2017, 374-381 [http://doi.org/10.5281/zenodo.259588].

[16] Slavova-Nocheva M.: Competitiveness of the transport market in Bulgaria. Economic Studies 21(3), 2012, 15-24.

[17] Vats B., Kumar Singh A.: Solving transportation problem using excel solver for an optimal solution. MIT International Journal of Mechanical Engineering 6(1) 2016, 18-20.

[18] Verga J., Silva R. C., Yamakami A.: Multimodal transport network problem: Classical and innovative approaches. Studies in Fuzziness and Soft Computing, Springer Verlag 358, 2018, 299-332 [http://doi.org/doi:10.1007/978-3-319-62359-7_14].

[19] Virtanen S., Klami A., Khan S.A., Kaski S.: Bayesian group factor analysis. The Journal of Machine Learning Research 22, 2012, 1269-1277.

[20] Zabolotnii S., Mogilei S., The methods for determining the parameter of the objective function of multimodal transportation risk. Proceedings of V International Scientific-Practical Conference "ITEST-2020", 2020, 114-115.

[21] Zabolotnii S., Mogilei S.: Optimization of the method of constructing reference plans of multimodal transport problem. Technological audit and production reserves 2(45), 2019, 15-20 [http://doi.org/10.15587/2312-8372.2019.154561].

[22] Zelenika R., Sever D., Zebec S., Pirš B.: Logistic operator: Fundamental factor in rational production of services in multimodal transport. Promet Traffic\&Transportation 17(1), 2005, 43-53.

[23] Zhao S., Gao C., Mukherjee S., Engelhardt B. E.: Bayesian group factor analysis with structured sparsity. Journal of Machine Learning Research 17, 2016, 1-47.
D.Sc. Serhii Zabolotnii

e-mail: zabolotniua@gmail.com

Serhii Zabolotnii was born in 1973 in Cherkasy, Ukraine. In 1995 he graduated the Departmen of informational technologies of Cherkasy State Technological University. Doctor of Technical Sciences (2015).

Job: professor of the Department of Computer Engineering and Informational Technologies in Cherkasy State Business-College. Scientific interests: statistical data processing, computer modeling. Author/co-author of more than 150 publications, 1 monography and 7 patents.

http://orcid.org/0000-0003-0242-2234

\section{Ph.D. Eng. Artem Honcharov}

e-mail: a.honcharov@chdtu.edu.ua

Graduated the Department of Electronic Technologies of Cherkasy State Technological University in 2001. First Vice-Rector of Cherkasy State Technological University. Associate professor of the Department of Robotic and Telecommunication Systems and Cyber Security in Cherkasy State Technological University. Scientific interests: signal processing, computer modeling.

https://orcid.org/0000-0003-4043-5300

M.Sc. Sergii Mogilei

e-mail: sergiymogiley@gmail.com

Sergii Mogilei is a Ph.D. student in Cherkasy State Technological University and works as a tutor in Rauf Ablyazov East European University (Cherkasy, Ukraine). His main scientific interests include mathematical and computer modeling, business analysis, mathematical programming, decision making theory and logistics.

http://orcid.org/0000-0002-9296-6827
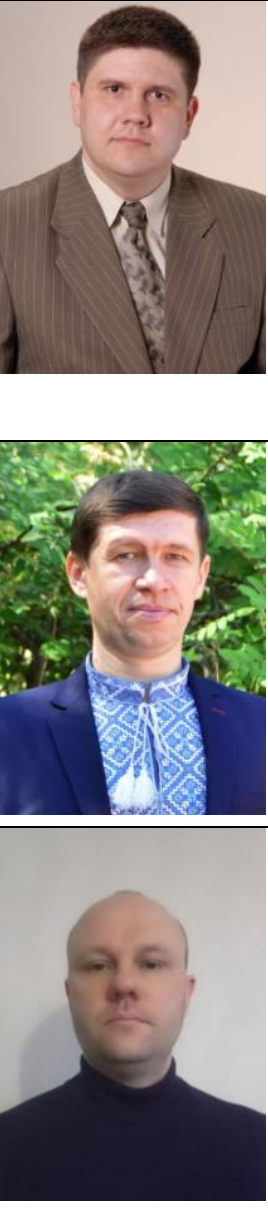

otrzymano/received: 20.10 .2021

przyjęto do druku/accepted: 15.12.2021 